\title{
IMPORTANCE OF BAZAARS AS CULTURAL COMMERCIAL SPACES: ERZURUM EXAMPLE
}

DOI: http://dx.doi.org/10.18509/GBP.2016.30

UDC: 339.175(560)

\section{Assist. Prof. Dr. Namık Tanfer ALTAŞ}

Atatürk University, Faculty of Education, Department of Geography Education, Erzurum, Turkey

\begin{abstract}
In the world where capitalism is getting stronger day by day, shopping malls, an element of capitalism, have gained a very important share in commercial activity. Together with the entrance of shopping malls to urban environments some of the local retailers in the cities tried to merge so as to continue their commercial lives while others could not stand against great capital and went bankrupt. Similarly to many of the Anatolian cities, it is possible to find bazaars in Erzurum. These bazaars carry the traces of history with the types of products sold and the places where trade is being made. These commercial spaces which an important place in the urban pattern are important areas of attraction with the products sold for shopping and the architectural properties they carry. Although majority are small scaled retailers, they are commercially very active as they sell local and cultural products, as they have been located in the same place for many years and as they have a different spatial look. Most important ones among these are Rüstem Paşa Caravanserai (Taş Han-Stone Inn), Jewelry Bazaar (Stone Stores), Spice Bazaar (Hacllar InnBaharatçılar), Shoemakers Bazaar (Kavaflar), Coppersmiths Bazaar (Bakırcılar), Wool Bazaar (Kevelciler), Flea Market (Bat Bazaar), Dry Grains (Kuru Hapan) and Urbane Bazaar (Nazik Çarşı). Almost all of the bazaars placed are spatially located around Erzurum Castle and within the outer castle walls. The aim of this study is to analyze the properties, economical area of impact and basic problems of these bazaars which carry traces of Seljuk and Ottoman architecture.
\end{abstract}

Keywords: Bazaar, Commercial Space, Cultur, Erzurum, Turkey.

\section{INTRODUCTION}

"Çarşı" (Marketplace/Bazaar) (cihar-suk), is terminologically constituted by the combination of the Persian word cihar which means "four" and the Arabic word suk which means "alley, street". Marketplace in Turkish culture is an important spatial factor for the cities and also a public area being commonly used by all segments of the society. Various social and economic activities take place in this place of the city.[1] Marketplaces of the Ottoman era are located in specific areas of the cities which had been formed under the influence of traditional Middle Asian Turkish and Islamic urbanism culture. The intracity locations of the marketplaces are not determined randomly. The factors such as closeness to the castle or city walls, main roads and cultural areas had been crucial in the selection of marketplace sites. Therefore, the city markets of the Ottoman era had presented development in the areas effected by one or more of such factors. The marketplaces are not the areas solely for commercial activities but also a system 
containing many social facilities in which the production activities were carried out. Therefore they serve as the center of urban life.[2]

Most of the Anatolian cities bear the traces of Seljuk and Ottoman architecture. Moreover, Seljuk architecture is more dominant in some cities while Ottoman architecture is more dominant in some other cities. Therefore covered or open air trading environments such as caravanserais, covered bazaars, inns, marketplaces and bazaars are very common factors of the Anatolian cities.

The core of the artisan and craftsmen order is the marketplace with covered bazaar. Covered bazaar is a place for trading valuable goods as well as for storing jewelry and laundering money. The marketplace being the wide surrounding of this structure is known as fondaco in Italy, as guildhall in England and as kaufhalle in Germany. Such place is known as collegium publicum in Rome. Collegium is also known as colleague and bears the meaning of brotherhood. The lodge within the marketplace is an economical order which controls the order, production and consumption and the prices are set by means of price fixing. In the languages of all Anatolian and Balkan people, the words of marketplace-bazaar are synonymous in terms of being public and being open to everyone. The heart of the Ottoman cities beat in the Central Marketplace. All social groups containing both women and men can be found with all languages and dialects in this place.[3] The small marketplaces in each neighborhood are established in accordance with the same principle as the grand bazaars in the center and they contain all necessary shops. In general, each marketplace is reserved only for one artisan or craftsmen group (lodge) whereas the bakers, kebab makers, kitchens can be available amongst other lodges due to their necessary nature.[4]

There is a settlement in the marketplaces within the city of Erzurum subject to the research similar to the Seljuk and Ottoman urban texture and their distribution within the urban area and their present importance will be underlined in the following sections.

\section{PURPOSE AND METHOD}

The objective of this study is ascertaining the basic features and spatial distribution and examining the main problems of the marketplaces located within the commercial areas of the city of Erzurum which bear cultural importance. In line with this objective, we will try to find an answer to the question "Do the traditional marketplaces in Erzurum still have an economic importance despite the shopping malls increasing in number?"

In order for the study to reach its goal, the individuals who performed as tradesmen in traditional marketplaces have been interviewed and the functionalities and physical conditions of the subject commercial areas have been observed on site and some inferences have been made.

\section{LOCATION OF STUDY AREA AND GENERAL FEATURES}

Turkey has been established on a territory where the continents of Europe and Asia get closer to each other the most and serves as an important bridge between Eastern and Western civilizations. Having important land, sea, air and rail ways has made the country become a strategic transit route in terms of both commercial facts and power transmission lines. The field of study is the city of Erzurum located to the East of Turkey by the Eastern Anatolian Region borders which had remained on the Silk Road for centuries (Figure 1). The facts such as the long lasting winter season and the presence of Palandöken Mountain 
$(3157 \mathrm{~m})$ right to the south of the city create a rich potential in terms of winter tourism in the city that has a severe continental climate. The city which remains within the winter tourism corridor of Turkey has hosted the $25^{\text {th }}$ Winter Universiade in 2011.[5]

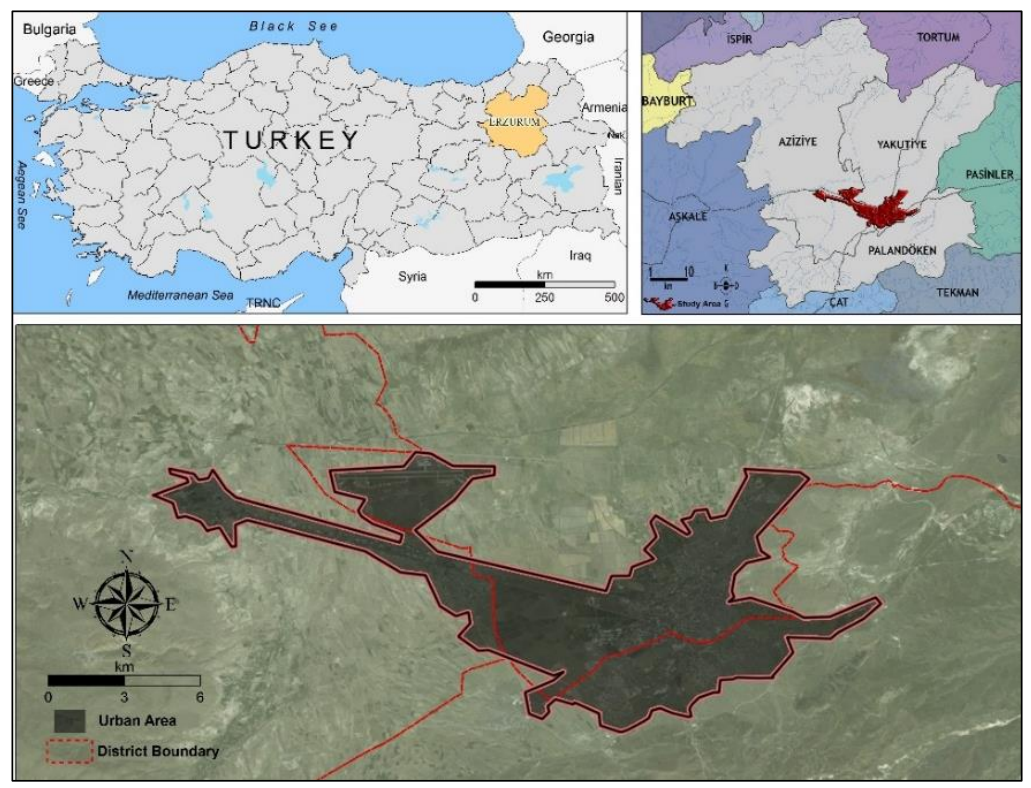

Figure 1. Location of study area.

\section{BAZAARS OF ERZURUM}

The city of Erzurum had always been a center of commerce where the trade between Iran, India and other Middle Asia countries and the Mediterranean was actively being carried out since the ancient times due to the geopolitical and geographical location of the city.[6] The city of Erzurum had developed in every respect when it was under the Ottoman rule. Particularly, generating substantial income from the caravans passing by the city as a result of the location being on the historical Silk Road had been effective in this sense.[7] Evliya Çelebi in his Travelogue mentions that there are almost 70 merchant inns in Erzurum in the XVII. Century and the customs of Erzurum is the busiest after the customs of İstanbul and İzmir.[8] Such importance of the city has been maintained until present and it has been an important service and trade city for the region. The city of Erzurum with such feature has always had many inns and caravanserais within the surrounding of the castle and its immediate vicinity. The caravans coming to the city used to carry out commercial activities around such inns and take the road again. Such commercial places all remain within the walls of the castle protecting the city.

The structures such as marketplace, bazaar, inn, covered bazaar within the city are traditional trading areas. Besides these, the business centers and Shopping Malls occupying wider areas and at many items are being sold together have substantial shares in commerce. The Shopping Malls are important in terms of providing service by bringing the world's leading brands not only to the city but also to the entire region. Establishment of the Shopping Malls in Erzurum was before the Winter Universiade in 2011.[9] The first one of these is Forum Erzurum which was opened in 2009 at Dörtyol area. The Shopping Mall which contains the stores of many national and international companies is able to drag many local tourists from the surrounding provinces even just for shopping by attracting them with the cinemas, restaurants, cafeterias, readymade clothing and electronics stores. Another Shopping Mall is Palerium which was opened in the city 
center in 2014 does not have a particular difference from Forum Erzurum in terms of functional features whereas its most important feature is its location being on the most crowded area of the city that is Cumhuriyet Street. Also there are two Shopping Mall constructions in progress as one in Yenişehir neighborhood and the other one in the former Coach Station area. Besides the abovementioned, there are stores and shops in service in more than 10 business at various areas.

A vast amount of the historical marketplaces which effects the urbanization of Erzurum in terms of commercial business places were constructed during the Ottoman era and in the first years of the Republic. The historical marketplaces have been located spatially around the Castle of Erzurum. However a substantial amount of them are located to the North of the castle. In order to provide their security, the marketplaces were established within the castle walls. There are gates between the castle walls providing the security control of the access to the city. The names of such gates were being given according to the directions where the caravans approach from or depending on the destinations of the departing caravans. These gates which still remain in the city can be used for various purposes in terms of functionality. Kavakkap1 Gate opens to the North, Karskap1 Gate opens to the East and South, İstanbulkap1 Gate opens to the West and Harputkap1 Gate opens to the Southwest. A very small portion of Harputkap1 Gate and most of the other three gates still remain standing and enlightens the historical mission of the city.

Only seven of the historical inns having importance in the commercial life of the city could reach to the present. These inns are; Cennetzade Inn, Gümrük Inn, Hacilar Inn, Hapan Inn, Kamburoğlu Inn, Komisli Inn and Taş Inn (Rüstem Paşa Caravanserai).[10] Taş Inn is still functional, however some of them has become ruins due to lack of maintenance and the rest are still being tried to be renovated within the scope of new projects.

We can make a list of the bazaars in the city of Erzurum still culturally being used in an active manner in the present day as below (Figure 2):

\section{Rüstem Paşa Caravanserai (Taş Han - Stone Inn):}

This structure is located on Menderes Street and was built by Sinan the Architect between 1554-1561 upon the order of Damat Rüstem Pasha the son-in-law and the grand vizier of Suleiman the Magnificent. The structure was restored in 1970 by the General Directorate for Foundations and the upper floor is reserved entirely for Oltu Stone production and sales while the ground floor shops are distributed between Oltu Stone tradesmen and other artisans and craftsmen. This market place referred to as Taşhan is the only two storey specimen amongst the historical marketplaces of the city. In the marketplace which attracts many local and foreign tourists, the rare examples of Oltu Stone works being one of the important values of Erzurum are being sold (Figure 3).

This stone being mined from Oltu district of Erzurum has been being processed for 200 years, however it has gained importance by the introductions and marketing following the foundation of the Republic. What makes this place cultural is the profession being handed down from father to son and the craftsmen gaining their professional experience by working at the workshops with their fathers. Generally the sons take over the sales shops after their fathers and continue with the business.[11] Most of the products being sold in Taşhan are the specimens of Erzurum handcrafts being mostly prayer beads, necklaces, rings, earrings and bracelets. Majority of the products are plain Oltu Stone and silver and gold inlaid Oltu Stone. This place is traditionally and culturally important because of these features. 


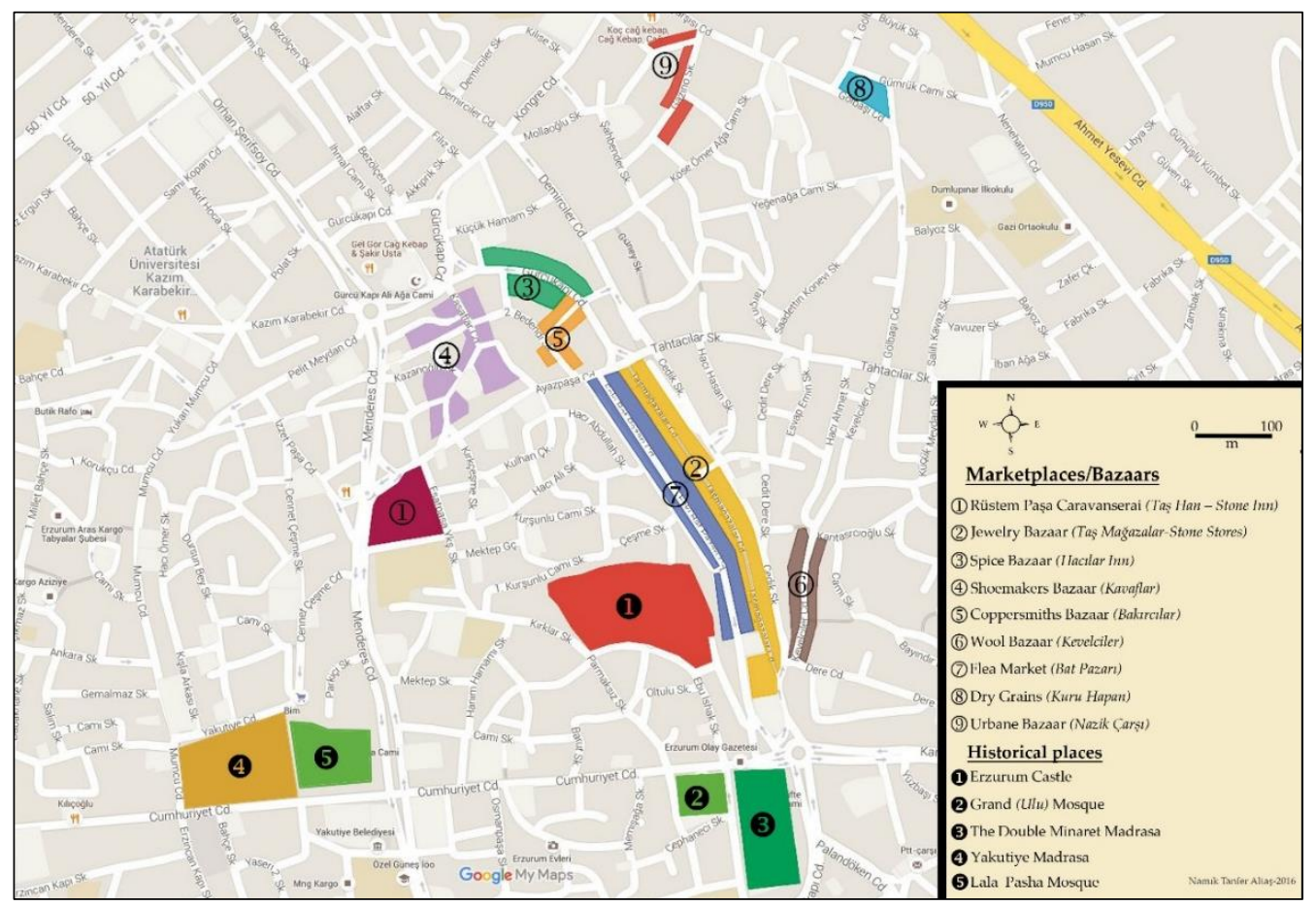

Figure 2. Spatial distribution of bazaars in Erzurum city.

\section{Jewelry Bazaar (Stone Stores):}

The Stone Stores which have an important place in the texture of the city is a shopping area closed to traffic which has stores and shops on both sides lying between Tebrizkap1 Gate and Tahtacilar Street to the North-South directions (Figure 3). It is a place mostly for gold and silver trade and for trousseau marketing. In recent years readymade garments and white appliances have also entered this area in a minor context. This historical area is important in terms of production and marketing of gold handcrafts which is one the handcrafts in Erzurum.

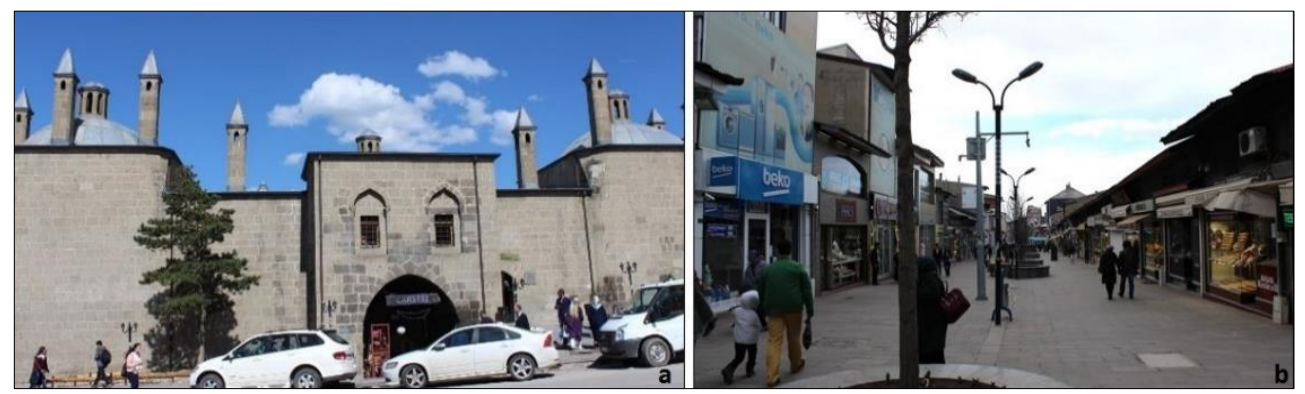

Figure 3. Rüstem Pasha Caravanserai and Jewelry Bazaar.

\section{Spice Bazaar (Hacular Inn)}

The place located on the Gürcükapı Street proceeding from the end of the Jewelry Bazaar to the Northwest is the area where former Hacilar Inn was located at (Figure 4). There are shops which sell mainly spices and natural medicines as well as hardware, readymade garments and white appliances on the outer front of the Hac1lar Inn which was built in the $18^{\text {th }}$ Century. This place has been the center of the spice trade being carried out in the city located on the historical Silk Road. 


\section{Shoemakers Bazaar:}

The place is located along the street starting from the East of Hacilar Inn and reaching the Ayaz Pasha Street to the South. Production and marketing of leather booties and a type of shoe being used by the Dadaş is the extinguishing feature of this marketplace. In this marketplace also the items with cultural values such as tea urns, stoves and braziers are being manufactured. Tea urn is a kitchen equipment which allows the tea - which is a popular beverage in Erzurum - to be steeped on wood fire and it is available almost in every home.

\section{Coppersmiths Bazaar}

The marketplace which starts with the $2^{\text {nd }}$ Bedendi Street right to the East of Ayazpaşa Mosque meets the Bakırcilar Street and ends at the opposite side of the Habip Baba Tomb by the end of the street. This is a place where mostly kitchenware made of copper are being manufactured and marketed. It has a cultural importance since the products being sold here are handcrafts.

\section{Wool Bazaar}

It is located on the street starting from the South part of the Stone Shops proceeding to the North and ends at Tahtacilar slope. It was a marketplace where the products such as scarves, beanies, vests and trousers made of wool were being manufactured and marketed. However the people involved in such business has decreased in number at the present time.

\section{Flea Market}

The markets most of the Anatolian cities under Ottoman rule where second hand items were being sold and bartered are referred to as Bayat Pazarl (Aged Bazaar) or Bat Pazart. It is located on the street laying in parallel to the west of Stone Shops (Figure 4). The marketplace currently contains the occupational groups such as curtain sellers, furniture dealers, chest makers, tailors etc. and its initial function is vanished.

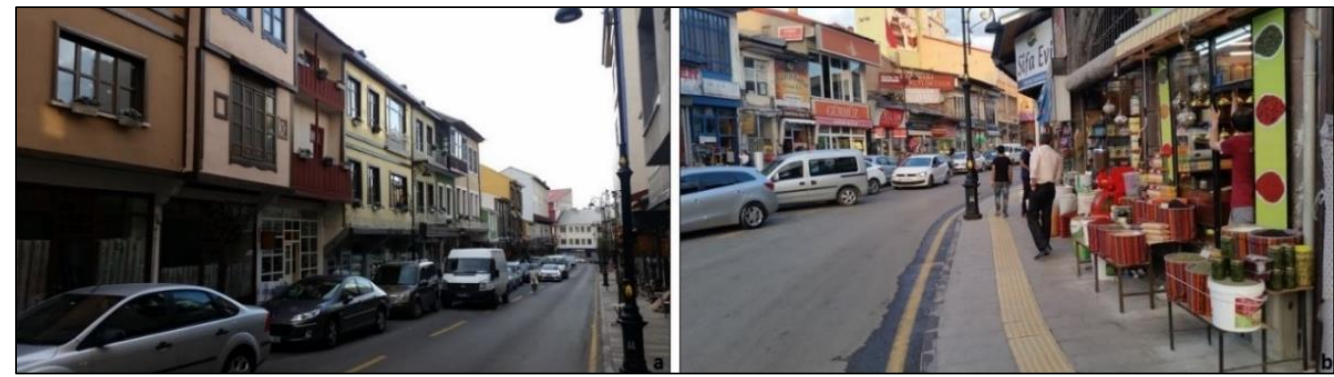

Figure 4. Flea Market (Bat Bazaar) and Spice Bazaar.

\section{Dry Grains (Kuru Hapan)}

It is located on Gölbaş1 Street crosswise to the Kamburoğlu Inn. Even though it is physically in bad conditions, it still remains as a center for dry food.

\section{Nazik (Urbane) Bazaar}

It had been one of the most important marketplaces in the history due to its location being close to Gümrük, Kamburoğlu and Develer Inns established during the Ottoman era. It starts from Kongre Street, proceeds towards Southeast and ends at Gölbaşı Street. It is currently being used as a dry food marketplace. 


\section{RESULTS}

\section{The following outcomes have been obtained as a result of the study:}

- Increasing day by day, the competitive market takes its share from these marketplaces where mostly the local tradesmen are carrying out their commercial activities. The trading volumes of the stores selling garments, shoes and electronics in the city have substantially decreased after the appearance of Shopping Malls in the city. However, most of the marketplaces being mentioned still remain lively in terms of trading due to reasons such as being historical marketplaces of the city, the items being available in these marketplaces but not at the Shopping Malls (or being available on a minimum level), the shopping manners of the people of Erzurum and the business being carried out with local capital and by local tradesmen.

- The business places carrying out their activities in the marketplaces mentioned during the study are important in terms of both being local tradesmen and most of them marketing the local handcraft works.

- The entirety of the marketplaces is of historical nature and they bear the traces of traditional and cultural values. In terms of urban landscaping, the marketplaces have the features which create the identity of the city.

- The entirety of the marketplaces is located between the inner walls and the outer walls of the castle. It appears that the seven of the marketplaces (Taşhan, Stone Shops, Spice Bazaar, Coppersmiths, Shoe Makers, Wool Bazaar, Flea Market) are located within a radius of 350 meters when the Castle of Erzurum is in the center of such circle.

- Rüstem Pasha Marketplace amongst the marketplaces is the most well-kept one. In recent past, the Jewelry Bazaar (Stone Shops) has been closed to traffic and been made more convenient for shopping. Flea Market has become more harmonious with the traditional architecture of the city by means of the restoration works in 2015 . The former architecture has been preserved and the business places on the ground floor have been furnished with a standard exterior, and the upper floors have been restored based on the exteriors of traditional Erzurum houses in order to maintain the cultural features. However, the physical conditions of the inns and marketplaces other than those are observed to be rather unfavorable.

\section{SUGGESTIONS}

\section{If we have to make suggestions as a result of the study:}

- Some projects may be developed for the mentioned marketplaces to maintain their commercial importance in the future as well. Some of the occupational groups in the marketplaces (coppersmiths, woolen garment makers) are at the edge of extinction. Some of the vocational high school students may be directed into such type of professions by means of the trainings to be provided by the chamber of merchants and craftsmen. By this way the traditional handcrafts of the city can be carried into future. For instance; as in the example of Castle of Gaziantep and its vicinity, such occupational groups may carry out manufacturing and sales in both covered and open air marketplaces which reflect the identity of the city within a cultural texture.

- Hacilar Inn across Habip Baba Tomb and its vicinity must be restored faithfully. We are of the opinion that the most proper action would be situating only the spice shops and the shops selling natural medicines within this place. 
- We are of the opinion that the Flea Market Street will be a marketplace where the features of the traditional architecture will be displayed the best by the completion of the restoration works on the South half of the Flea Market.

- Dry Grains (Kuru Hapan) is physically in bad conditions. Kamburoğlu Inn is planned to be restored by the Yakutiye Municipality. Together with such restoration, the tradesmen of the Kuru Hapan (Dry Grains) are intended to be moved to this place. Realizing this project will be accurate. Only in this manner we can hand down our cultural values to the next generations.

- A substantial part of the inns which have been neglected unnoticeably (Gümrük, Hapan, Cennetzade, Kamburoğlu, Hacılar, Komisli Inns) are being used as storehouses. In order to meet these inns with their former missions in history, projects must be developed and the restoration works must be accelerated by means of the studies to be carried out in cooperation with Erzurum Metropolitan Municipality and Yakutiye Municipality, Chamber of Merchants and Craftsmen, Provincial Directorate of Culture and Tourism, and the concerning academicians of the Ataturk University. By this means, the incomes of the city generated from tourism will increase and the identity of the city of Erzurum will become clearer in the field of traditional commerce.

\section{REFERENCES}

[ $\left.{ }^{1}\right]$ Uysal, M., Tarihsel Süreçte, Geleneksel Konya Çarşısı İçin Bir Mekânsal Analiz, Milli Folklor Dergisi, Say1:86, 2010, pp.149-162.

$\left.{ }^{2}\right]$ Şahinalp, M.S., Günal, V., Osmanlı Şehircilik Kültüründe Çarşı Sisteminin Lokasyon ve Çarşı İçi Kademelenme Yönünden Mekânsal Analizi, Milli Folklor Dergisi, Sayı:93, 2012, pp.149-168.

[3] Mortan, K., Küçükerman, Ö., Çarşı, Pazar, Ticaret ve Kapalıçarşı, Türkiye İş Bankası Kültür Yayınları, İstanbul, 2011, pp.69-70.

[ $\left.{ }^{4}\right]$ Hizmetli, M., Tarihte Şehir ve Pazar, Aştırma yayınları, Ankara, 2012, pp.201.

[5] Doğanay, H., Zaman, S., Türkiye Turizm Coğrafyası, Pegem Yayınları, Ankara, 2013, pp.58.

[6] Pamuk, B., XVII.Yüzyılda Bir Serhad Şehri Erzurum, IQ Kültür Sanat Yayıncılık, İstanbul, 2006, pp.305.

[7] Kayserili, A., Erzurum Şehri'nin Kültürel Coğrafyas1, Zafer Ofset, Erzurum, 2014, pp.101.

[8] Evliya Çelebi, Evliya Çelebi Seyahatnamesi, (Haz: Seyit Ali Kahraman, Yücel Dağlı), İkinci Kitap, Yapı Kredi Yayınları, İstanbul, 2013.

[9] Altaş, N.T., Coğrafi Çevre Unsurlarıyla Şehirleşme Etkileşimi Bakımından Erzurum Şehri, Pegem Akademi Yayınevi, Ankara, 2015, pp.144.

[10] Köşklü, Z., Erzurum' da Osmanlı Dönemi Hanları, Sosyal Bilimler Enstitüsü Dergisi, Say1:5, 2010, pp.113-134.

[11] Alparslan, E., Oltu Taşı İşlemeciliği ile ilgili Faaliyet Gösteren Bireylerin Demografik Özelliklerinin ve Mesleğe İlişskin Görüşlerinin Belirlenmesi, Gazi Üniversitesi, Endüstriyel Sanatlar Eğitim Fakültesi Dergisi, Say1: 26, 2010, pp.40-56. 